\author{
ANNALS OF THE \\ UNIVERSITY OF CRAIOVA
}

Series: $\checkmark$ Biology

$\checkmark$ Horticulture

$\checkmark$ Food products processing technology

$\checkmark$ Environmental engineering

Vol. XXVI (LXII) - 2021

\title{
CONTRIBUTION TO THE KNOWLEDGE OF THE CADDISFLY LARVAE (TRICHOPTERA) FROM RÂNCA RESORT - PARÂNG MOUNTAINS, ROMANIA
}

\author{
Babalean Anda Felicia1* \\ ${ }^{1 *}$ University of Craiova, Faculty of Horticulture \\ * Correspondence author. E-mail: anda_babalean@yahoo.com
}

Keywords: Trichoptera (caddisfly), larvae, Parâng Mt.

\begin{abstract}
This paper presents the main morphological characters of some Trichoptera larvae from Rânca Resort (Parâng Mountains), larvae belonging to two families - Rhyacophilidae and Limnephilidae. Based on the morphological characters, the larvae are identified at the genus level - Rhyacophila, Potamophilax, Drusus, Chaetopterigopsis and at the species level Rhyacophila philopotamoides McLachlan, 1879.
\end{abstract}

\section{INTRODUCTION}

Caddis larvae are some of the most familiar inhabitants of the mountain water bodies. Their study has practical importance (saprobic valencies) as well as theoretical importance in faunistical, biogeographical, ecological research. The knowledge of the caddis larvae is part of general knowledge of Trichoptera. Although the same invertebrate group, the study of adult and larval Trichoptera became distinct fields, with dedicated identification manuals.

The identification of caddis larvae to species level is not an easy task, the larvae of some species being almost identical. It is the case of the so called "species pair" when it is recommended that *the separation between species should be supported by adult catches* (Waringer \& Graf 2011). However, there are cases when larval stages are described without association with adult species (for instance Botoșăneanu 1956).

In this paper, several caddis larvae collected from Rânca Resort on different occasions are morphologically presented.

\section{MATERIAL AND METHODS}

The material was sampled from reocrene springs and associated waterbodies - brooks and streams, puddles on the route of spring brooks. The material is preserved in $70^{\circ}$ ethyl alcohol and stored in the collection of the Faculty of Horticulture, University of Craiova under the register numbers given between brackets for each larva. The morphological characters provided by the key in the Atlas of Central European Trichoptera larvae (Waringer \& Graf 2011) were used to assign the larval forms to a taxonomic level. The descriptive text in italics shows the morphological differences between the collected material and that of the Atlas. 


\section{Fam. Rhyacophilidae}

\section{RESULTS AND DISCUSSIONS}

Larva 1 - Rhyacophila sp. (Figs. 1, 2, 3), legit A.F. Babalean, 5 July 2021, reocrene spring, (33.AFB - TR-I1)

Morphological characters:

- abdominal gills present, multifilamentous

- comb-like gills with two unequal branches

- the dorsal muscle attachment spots of the head are significantly darker than the surrounding pigmentation

R. torrentium

- ventral side of the head partly dark

R. evoluta

- the distal tooth of the anal claw is shorter than the width of the anal claw at the distal point of origin of this tooth

- $\quad$ anteclypeus with 3 dark longitudinal bands

R. polonica

R. praemorsa

Discussions

The head of this species larva shows mixed characters (characters of more than one species): torrentium, evoluta, polonica/praemorsa. The dorsal head and pronotum are more similar with $R$. praemorsa.

Only $R$. torrentium and $R$. polonica are cited in the Romanian fauna (Ujvárosi et al. 2008, Ciubuc 2010).

Larva 2 Rhyacophila tristis/aquitanica. (Fig. 4), legit A.F. Babalean, 5 July 2021, stream in the teleski area, (34.AFB-Tr-I2)

Morphological characters:

- abdominal gills lacking

- anal claw without ventral teeth

- ventral head surface dark-coloured; dorsal head surface mostly darkcoloured

Discussions

The morphological characters indicate the species pair Rhyacophila tristis/aquitanica. Both species are present in the Romanian fauna (Ujvárosi et al. 2008, Ciubuc 2010). The morphological characters *do not permit a reliable separation of the two species* (Waringer \& Graf 2011).
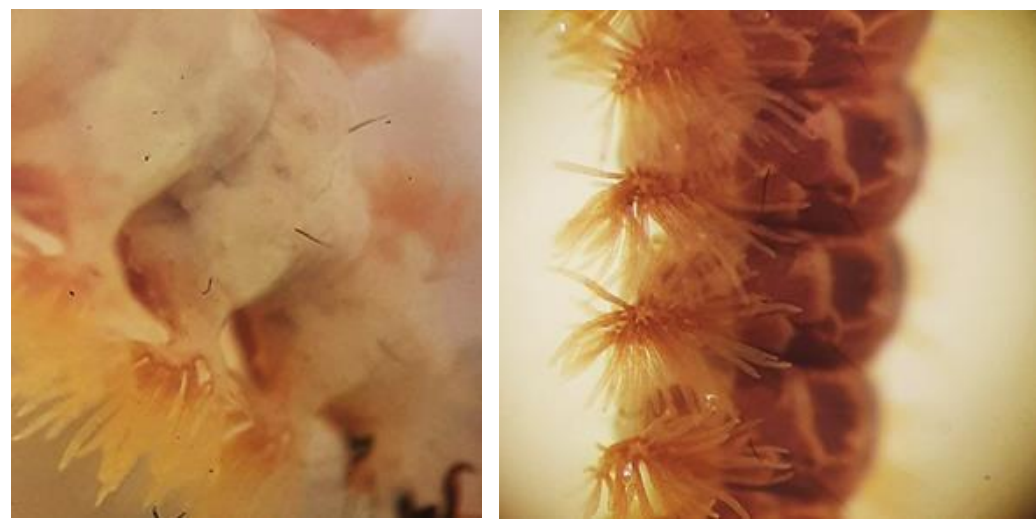

Figure 1. Rhyacophila sp. - left and right - multifilamentous abdominal gills 

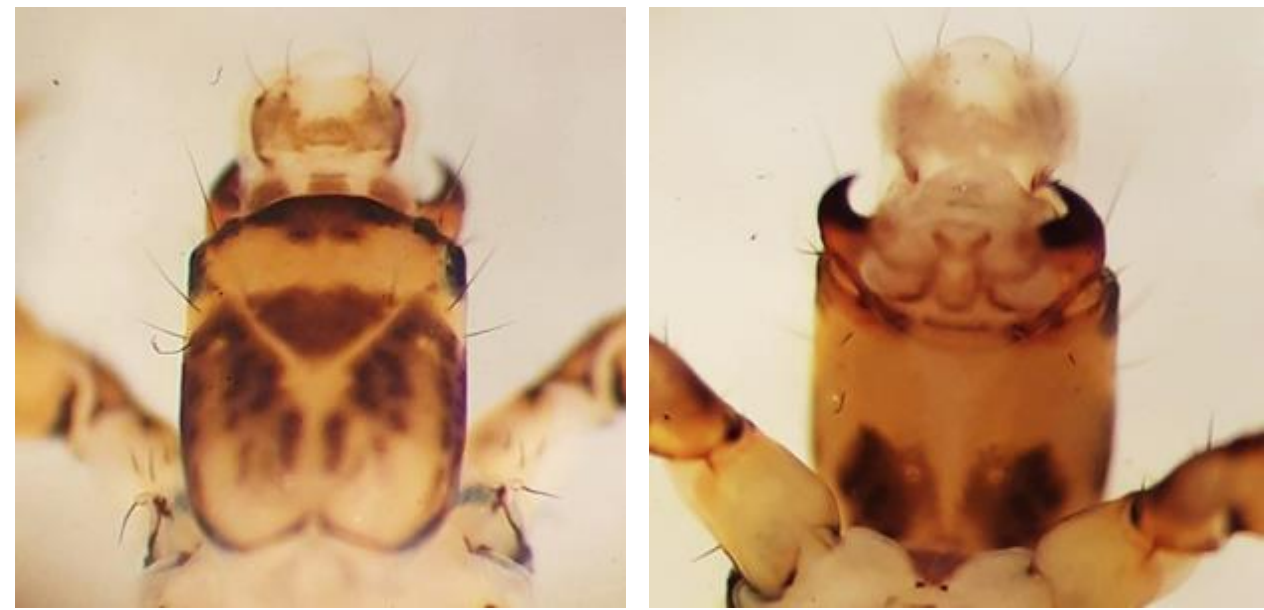

Figure 2. Rhyacophila sp. - the head on dorsal view (left) and on ventral view (right)
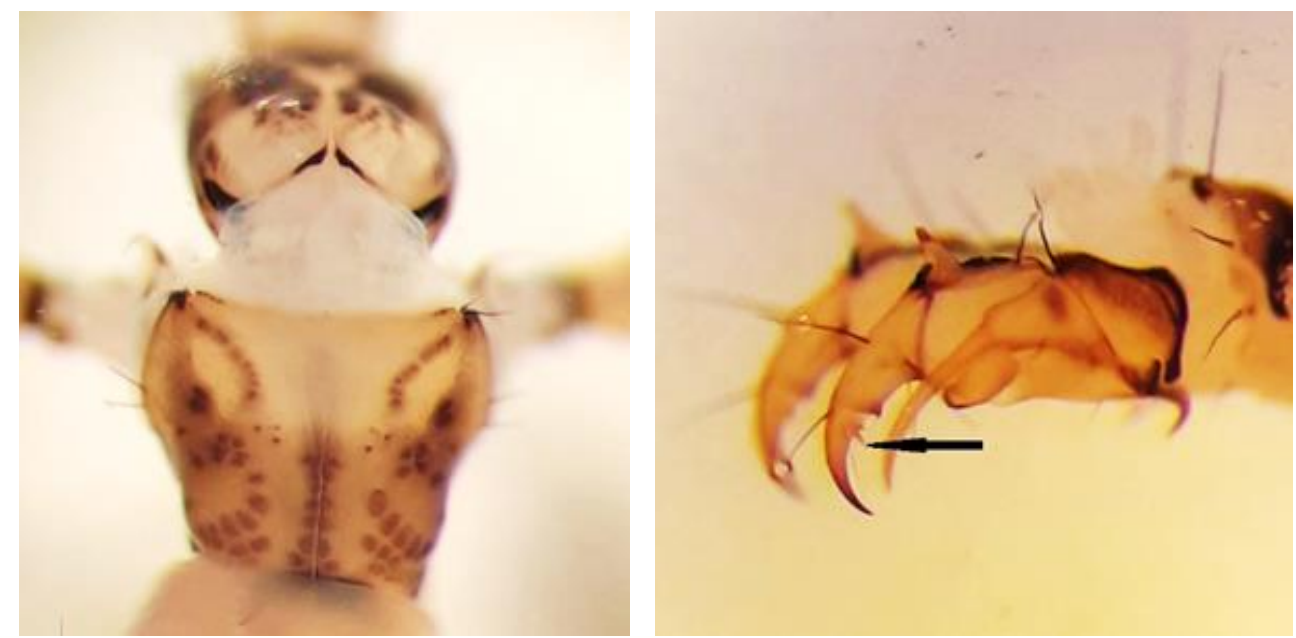

Figure 3. Rhyacophila sp. - left: pronotum on dorsal view; right: the anal claw
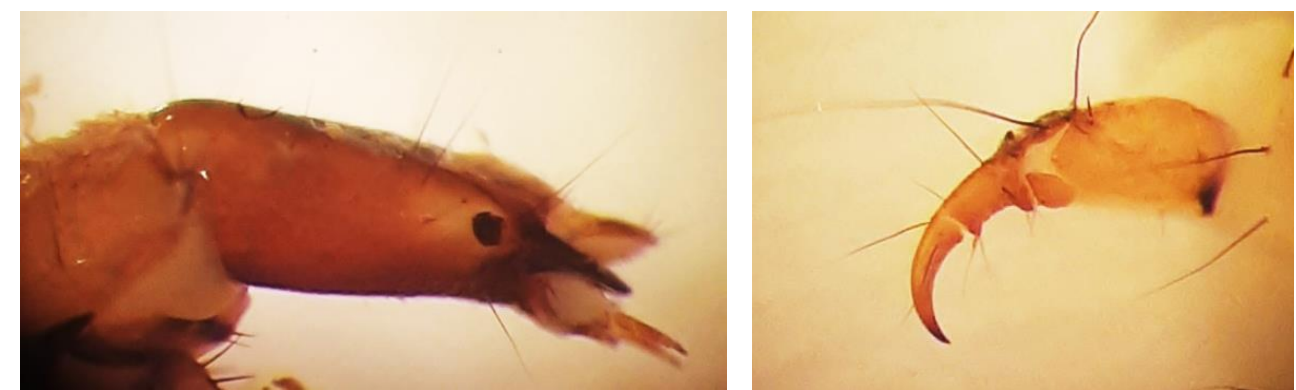

Figure 4. Rhyacophila tristis/aquitanica - left: the head in lateral view; right - the anal claw 
Larva 3 Rhyacophila philopotamoides (Fig. 5), legit A.F. Babalean, 5 July 2021, reocrene springs, (35.AFB - TR-I3)

Morphological characters:

- abdominal gills lacking

- anal claw with ventral teeth

- posterior third of head capsule constricted laterally

- dorsal head surface with dark muscle attachments ...... R. philopotamoides Discussions

The morphological characters lead to Rhyacophila philopotamoides.

Figure 5. Rhyacophila philopotamoides - left: the anal claw; right: the head, pronotum and mesonotum

\section{Fam. Limnephilidae}

Larva 4 Drusus romanicus/discolor (Fig. 6), legit unknown student, July 2000 (36.AFB - TR-14)

Case - conical, made of sand and very small pebbles.

Larval morphological characters:

- abdominal dorsal and ventral gills consist of single filaments

- $\quad$ rows of long filtering bristles at the first abdominal sternum and legs

- head and pronotum covered by a dense layer of woolly hairs, character Discussions which indicate the species Drusus discolor or D.romanicus

Botoșăneanu (1959) notes that "the identity of the romanicus and discolor larvae is astonishing" and evaluates that the species $D$. discolor is very rare in the Romanian Carpathians.

Figure 6. Drusus discolor/romanicus - head and pronotum covered by woolly hairs 
Larva 5 Potamophylax nigricornis/pallidus (Figs. 7, 8, 9), legit A.F. Babalean, 5 July 2021, puddle alongside spring-fed stream, (37.AFB - TR-15)

Case - cylindrical tube, made of sand and small pebbles, with vegetal debris in the back.

Larval morphological characters:

- sclerites on pro-, mezo-, metanotum

- mesonotum with 2 large sclerites in close contact

- metanotum incompletely sclerotised, 3 pairs of metanotal sclerites of different shape and arrangement

- prosternal horn present

- fleshy laterally protuberances on the first abdominal segment; fleshy dorsally protuberances on the first abdominal segment merely visible

- antenna distinctly (approximately one eye diameter) offset from anterior eye margin

- abdominal dorsal and ventral gills with one single filament

- cutting edge of mandibles with teeth

- first abdominal sternum with shorter setae and few long setae arranged in an irregular pattern

- anterior third of pronotum with transverse rim

- posterior section of lateral fleshy protuberances with a large sclerite without setae

- dorsal edge of hind femora with a single proximal seta and several distal setae

- $\quad$ ninth abdominal segment with a group of postero-lateral setae

- pronotum concolorous

- $\quad$ pronotum with numerous short black spines and setae nigricornis/pallidus

Discussions

The morphological characters indicate the species pair Potamophylax nigricornis/pallidus, which are *not yet morphologically separable* (Waringer \& Graf 2011).
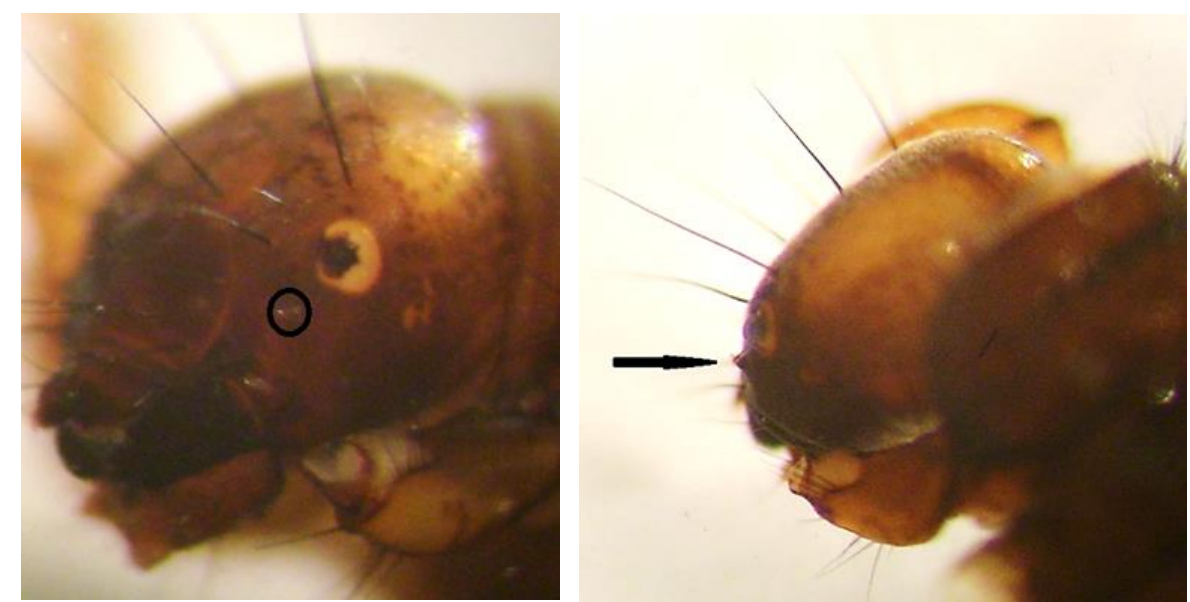

Figure 7. Potamophylax nigricornis/pallidus - the head with the antenna marked by a circle (left) and by arrow (right) 

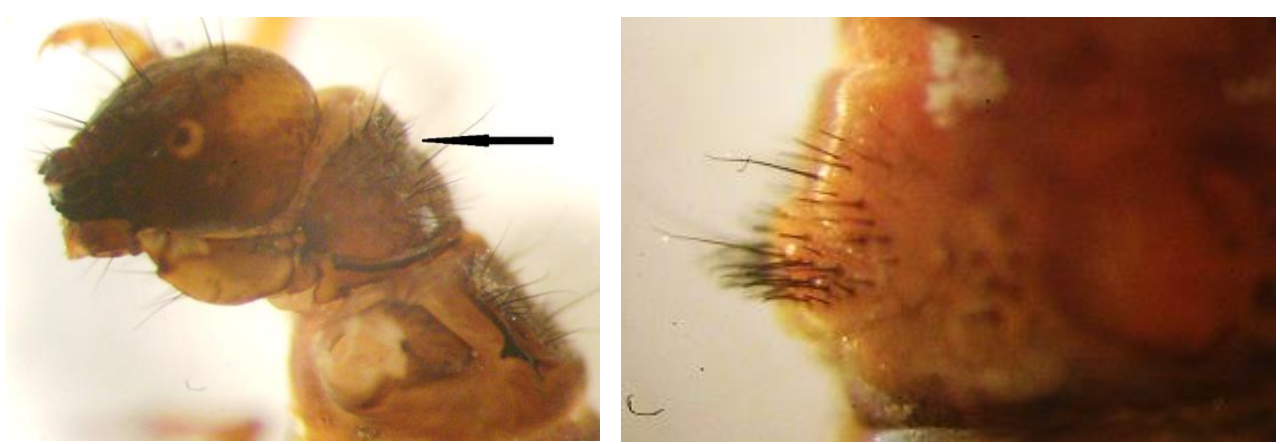

Figure 8. Potamophylax nigricornis/pallidus - left: pronotal rim; right - first abdominal sternit

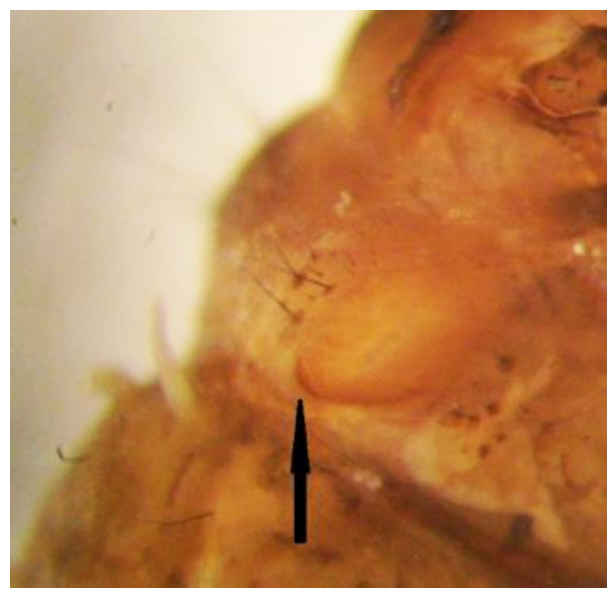

Figure 9. Potamophylax nigricornis/pallidus - left: the lateral fleshy protuberance with a large sclerite without setae; right: the ninth abdominal segment with a group

of postero-lateral setae

Larva 6 Chaetopterigopsis sp. (Figs. 10, 11), puddle alongside spring-fed stream, legit A.F. Babalean, 5 July 2021, (38.AFB- TR-16)

Case - made of foliaceous vegetal detritus

Larval morphological characters:

- all gills consisting of single filaments

- cutting edge of mandibles with teeth

- anterior third of pronotum with transverse rim

- posterior section of lateral fleshy protuberances at the first abdominal segment with a long sclerite without setae and with 2 small holes; a setal band absent anterior to the lateral protuberances

- the dorsal fleshy protuberance with a triangular horn

- dorsal edge of hind femora with a single proximodorsal seta and 2-3 distal setae

- ninth abdominal segment with only one posterolateral seta

- pronotum concolorous

- first abdominal sternum with large partly fused setal bases

- one central intermediate c-seta on dorsal sclerite of ninth abdominal segment 
- head capsule and body sclerites pale brown to brown

- head, pro-, meso- and metanotum covered only with long black setae Discussions

Excepting the italicised characters, the rest suggest the species Chaetopterygopsis maclachani, present in the Romanian fauna (Ujvárosi et al. 2008, Ciubuc 2012). However, it is not excluded that the sixth larval form of this paper may represent the species Chaetopterygopsis sisestii also present in the Romanian fauna (Botoșăneanu 1961, Ujvárosi et al. 2008, Ciubuc 2012), but for which, the larval stages are not described.
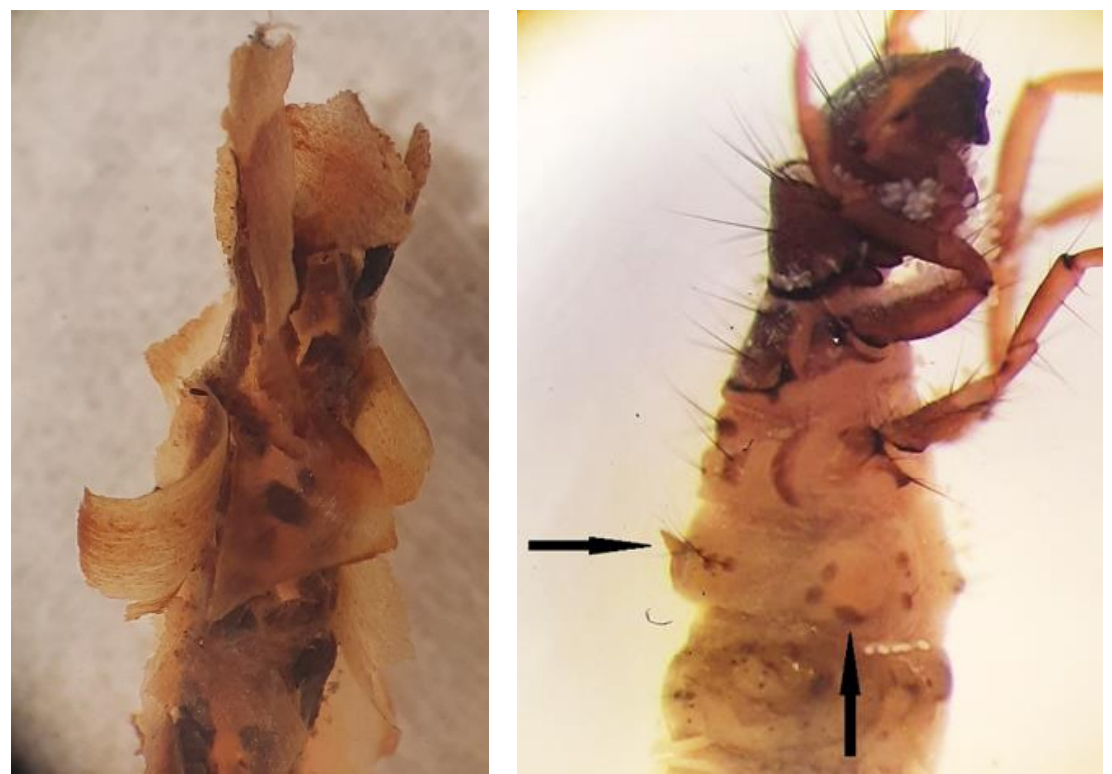

Figure 10. Chaetopterigopsis sp. - left: the case; right: the head, pro-, meso- and metanotum covered only by long setae and the first abdominal segment showing the dorsal fleshy protuberance with a triangular horn and the posterior section of the right lateral fleshy protuberance with a sclerite without setae and with 2 holes

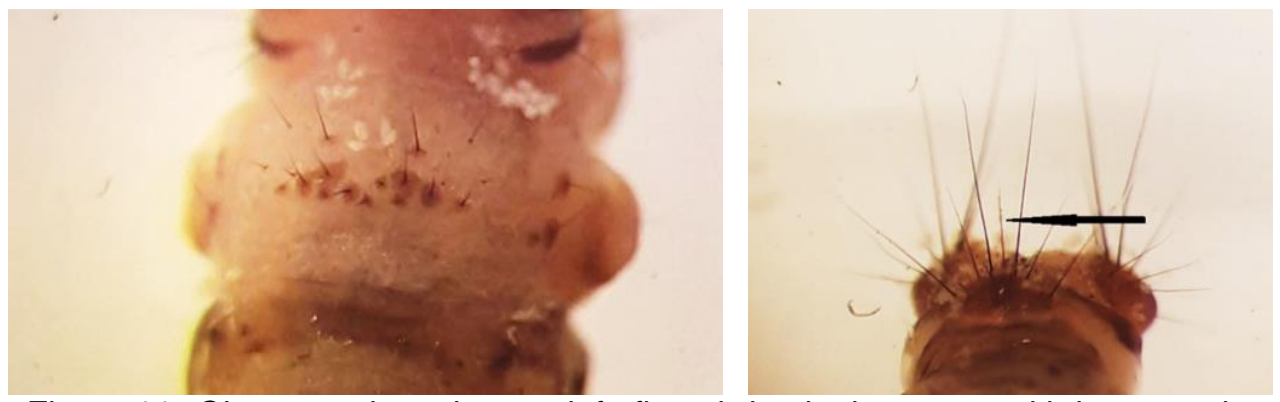

Figure 11. Chaetopterigopsis $s p$. - left: first abdominal sternum with large partly fused setal bases; right: one central intermediate c-seta on dorsal sclerite of the ninth abdominal segment 


\section{CONCLUSIONS}

1. The larval forms presented in this paper, with intermediate or slightly different characters than that of reliable literature (Waringer \& Graf 2011) may be associated with individual or clinal variation of some morphological characters, the existence of subspecies or even new species, intergradation (hybridization). When speaking of new species, it is worthy to note that in the case of some Trichoptera species, the geographic distribution is restricted to very small areas, for instance, a single mountain (Valladolid et al. 2021).

2. An integrated study of larval stages, imagos and molecular markers will give a complete picture of the Trichoptera fauna from Rânca Resort.

\section{ACKNOWLEDGMENT}

The author acknowledges the assistance of Mr. Mihai Marian and students in the field work and the help of dr. Andreea Bratu with the English translation of a former draft of the manuscript.

\section{REFERENCES}

Botoșăneanu L. 1956. Recherches sur les Trichoptères de Bulgarie recuillis par MM. le Prof. A. Valkanov et B. Rusev. Beiträge zur Entomologie, 6, 354-402.

Botoșăneanu L. 1959. Cercetări asupra Trichopterelor din Masivul Retezat și Munții Banatului. Biblioteca de Biologie Animală I, Editura Academiei R.P.R., pp. 165.

Botoșăneanu L. 1961. Trichoptères roumains nouveaux capturés en 1960 (Trichoptera). Mitteilungen der Schweizerischen Entomologischen Gesellschaft, 34, 1, 61-66.

Ciubuc C. 2010. Trichopterele din România, vol. I, Editura MiniEd, lași, pp. 299.

Ciubuc C. 2012. Trichopterele din România, vol. II, Editura MiniEd, lași, pp. 415.

Ujvárosi L., Robert S. C., Neu P., Robert B. 2008. First revision of the Romanian caddisflies (Insecta: Trichoptera). Ferrantia, 55, 110-124.

Valladolid M., Arauzo M., Chertoprud V. M., Chvoska P., Czachorowski S., Dorda B. A., Hinić J., Ibrahimi H., Karaouzas I., Krpač V., Kučinić M., Lodovici O., Salokannel J., Slavevska Stamenković V., Stojanović K., Wallace I., Rey I. 2021. The Rhyacophila fasciata Group in Europe: Rhyacophila fasciata Hagen 1859 and formerly synonymized species (Trichoptera: Rhyacophilidae), with new description of Rhyacophila fasciata and Rhyacophila septentrionis McLachlan 1865 (stat. prom.). Zootaxa 4975 (1): 001-057.

Waringer J., Graf W. 2011. Atlas of Central European Trichoptera larvae, Erik Mauch Verlag, pp. 467. 